\title{
EFFECT OF ANTISERUM TO RAT PROLACTIN ON MILK YIELD AND FOOD INTAKE IN THE RAT
}

\author{
J. SHANI (MISHKINSKY), G. GOLDHABER AND F. G. SULMAN \\ Department of Applied Pharmacology, School of Pharmacy, \\ Hebrew University, Ferusalem, Israel
}

\section{(Received 5th December 1974)}

Anti-ovine prolactin injected into the duct of a rabbit mammary gland inhibits the local lactogenic response of prolactin in the same duct (Saji \& Crighton, 1968), and inhibits the proliferative effect of concurrently-injected prolactin in the pigeon crop-sac assay (Hayashida, 1962). Anti-ovine prolactin also decreases the weights of the prostate and seminal vesicle of male rabbits (Asano, Kanzaki, Sekiguchi \& Tasaka, 1971). Anti-mouse prolactin has been reported to suppress the growth of mammary tumours in mice (Sinha, Lewis \& Vanderlaan, 1974) and to inhibit the biological activity of mouse prolactin as measured by the pigeon crop-sac test (Kosugiyama, Mori \& Nagasawa, 1970). Anti-rat prolactin injected into lactating rats lowered the progesterone secretion rate (Yoshinaga, 1973), while anti-human placental lactogen injected to pregnant rats during Days 1 to 5 of gestation reduced the weight of the young and increased their mortality (El Tomi, Boots \& Stevens, 1971). Sinha et al. (1971) injected anti-mouse prolactin to 4-day-old rats; $39 \%$ died within a few days of the injections, and there was poor growth of the surviving young. In a further experiment, Sinha et al. (1972) reported suppression of the growth of young rats after injecting anti-mouse prolactin into the mothers, and regarded this as suggesting involvement of prolactin in milk synthesis.

The present study involved the injection of anti-rat prolactin into lactating rats and, by subsequent measurement of their food and water intake in addition to the growth and survival of their young, determination of the effect on milk yield of neutralizing the endogenous prolactin.

Anti-serum to rat prolactin was prepared by a modification of the method described by Vaitukaitis, Robbins, Nieschlag \& Ross (1971) by intradermal injections into multiple sites in the necks of 2- to 3-month-old rabbits. The rat prolactin was dissolved in a minimal quantity of $1 / 10 \mathrm{~N}$ sodium hydroxide solution, made up to a final dilution of $0.1 \mathrm{mg} / \mathrm{ml}$ with phosphate buffer, and emulsified with twice the volume of Freund's complete adjuvant. Dried tuberculosis bacilli were then added by vigorous mixing to give a final concentration of $2.5 \mathrm{mg}$ bacilli/ $1 \mathrm{ml}$ emulsion, and the mixture was injected at a dose of 0.1 $\mathrm{mg} / \mathrm{rabbit}$. A booster injection was prepared by dissolving prolactin in sodium hydroxide solution and made up with phosphate buffer, $\mathrm{pH} 7 \cdot 6$, to a final concentration of $0.25 \mathrm{mg} / \mathrm{ml}$. The booster solution was injected intramuscularly into the paws, and the rabbits were bled 14 days later and the sera were assayed for anti-prolactin by the double-antibody system using NIAMD rat prolactin 
antigen. The 50\% precipitation titre was 1:20,000. The antiserum was frozen at $-20^{\circ} \mathrm{C}$ until use.

The antiserum used for injection into the lactating rats was emulsified in Freund's incomplete adjuvant to prolong its availability and permit single daily injections instead of the multiple daily injections which are commonly given when using hypophysial hormones. Lactating rats serving as controls received emulsified normal rat serum (NRS) by the same injection schedule.

Forty-eight lactating rats, of the Hebrew University Sabra strain and weighing 270 to $330 \mathrm{~g}$ each, were placed in separate cages on the day of parturition
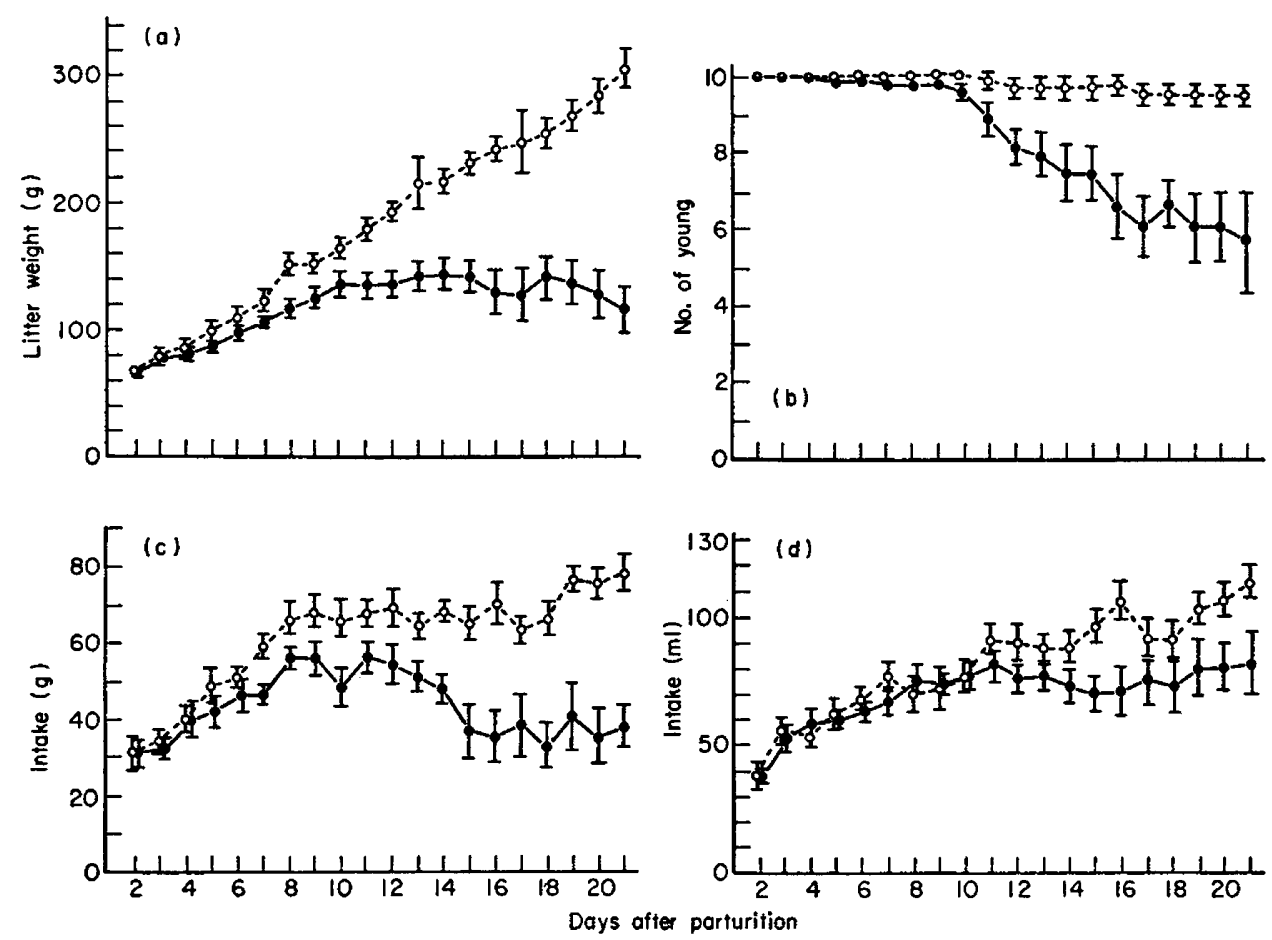

TexT-FIG. 1. Effect of antiserum to rat prolactin on (a) the litter growth (as an estimate of milk yield), (b) survival of young, and intake of (c) food and (d) water of lactating rats. The serum $(0.4 \mathrm{ml})$ was injected once daily subcutaneously on Days 2 to 20 after parturition. Experimental animals; $O$, control rats. The vertical bars represent the S.E.M.

and their litters were adjusted to ten young/mother. The body weights of the young (as an index for milk yield) and of the mothers, and the food and water intake of the mothers, were recorded as described previously (Weller, Shani, Givant \& Sulman, 1972). On the 2nd day after parturition the mothers were randomly allocated to four equal groups and injected daily with either antiserum to rat prolactin (Groups 1 and 2 received 0.1 or $0.4 \mathrm{ml} / \mathrm{rat}$, respectively) or NRS (Groups 3 and 4 received 0.1 or $0.4 \mathrm{ml} / \mathrm{rat}$, respectively), until the 20 th day after parturition.

No suppression in the milk yield or of the mortality of the young was noticed in Group 1, but a highly significant drop in milk yield and survival of the young 
was found in Group 2 on Days 8 and 12 after parturition, respectively. No loss of maternal body weight occurred, in spite of the fact that food intake fell shortly after the start of the treatment, and water intake was also suppressed for part of this period (see Text-fig. 1).

These results suggest that antiserum to rat prolactin decreases milk yield in lactating rats, and that this effect is associated with a reduction in maternal intake of food and water. As the reductions in milk yield and in food intake start on about the same day of lactation, it is impossible to decide which of them precedes the other. These results are in agreement with those of Sinha et al. (1972) and those of Bartke (1971) who reported that young born to mice congenitally deficient in prolactin died 2 to 8 days after birth, apparently from lack of milk. These results confirm the indispensability of prolactin in the maintenance of milk production in the rat.

The authors wish to thank Professor B. Lunenfeld of the Endocrinology Institute of the Sheba Medical Centre for his advice, and Dr R. H. Bates of NIAMD for the generous supply of rat prolactin for immunization and the kit for rat prolactin radioimmunoassay. This work was supported in part by the Joint Research Fund of the Hebrew University and Hadassah and by a research grant from the Research Promotion Fund of the Histadrut.

\section{REFERENCES}

Asano, M., Kanzakr, S., Sekiguchi, E. \& Tasaka, T. (1971) Inhibition of prostatic growth in rabbits with antiovine prolactin serum. F. Urol. 106, 248-252.

BARTKE, A. (1971) The maintenance of gestation and the initiation of lactation in the mouse in the absence of pituitary prolactin. F. Reprod. Fert. 27, 121-124.

EL Tomi, A. E. F., Boots, L. \& Stevens, V. G. (1971) Effects of antibodies to HPL on reproduction in pregnant rats. Endocrinology, 88, 805-809.

Hayashida, T. (1962) Immunological studies with pituitary lactogenic hormone. In Immunoassay of Hormones. Ciba Fndn Colloq. Endocr. Vol. 14, pp. 338-360. Eds. G. E. W. Wolstenholme \& M. P. Gameron. Little, Brown \& Co., Boston.

Kosugryama, M., Mori, J. \& Nagasawa, H. (1970) Some immunological properties of rabbit antiserum to mouse prolactin. Endocr. jap. 17, 251-255.

SAJI, M. A. \& GRIGhton, D. B. (1968) A study of the antihormonal activity of an antiserum to ovine prolactin using the local lactogenic response in rabbit. F. Endocr. 41, 555-561.

Sinha, Y. N., Lewis, U. J. \& VANDERLAan, W. P. (1971) Effects of prolactin and GH deficiency on the growth of neonatal mice. Proc. 53rd A. Meeting Am. Endocr. Soc., Abstract 166.

Sinha, Y. N., Lewis, U. J. \& Vanderlaan, W. P. (1972) Effects of administering antisera to mouse GH and prolactin on gain in litter weight and on mammary nucleic acid content of lactating C3H mice. 7. Endocr. 55, 31-40.

Sinha, Y. N., LEwis, U. J. \& VANDERLAan, W. P. (1974) Inhibition of mammary tumors by GH and prolactin antisera. Clin. Res. 22, 130-A, Abstr.

Vattukaitis, J., Robbins, J. B., Nieschlag, E. \& Ross, G. T. (1971) A method for producing specific antisera with small doses of immunogen. F. clin. Endocr. Metab. 33, 988-991.

Weller, C. P., Shani (Mishkinsky), J., Givant, Y. \& Sulman, F. G. (1972) Dissociation between the mammotrophic and galactopoietic effects of perphenazine and perphenazine sulfoxide in the rat. Archs int. Pharmacodyn. Thér. 200, 405-414.

Yoshinaga, K. (1973) Reduction of progesterone secretion by prolactin antiserum in lactating rats. Proc. 55th A. Meeting Am. Endocr. Soc., Abstract 471. 